Journal of Engineering and Applied Sciences 15 (6): 1359-1376, 2020

ISSN: 1816-949X

(C) Medwell Journals, 2020

\title{
The Arts Teacher's Paradigm for Arts Competition of Secondary School Level in Northeastern
}

\author{
${ }^{1}$ M. Napawan Purisa, ${ }^{2}$ D. Sippa Suksamran and ${ }^{3}$ Homhuan Buarabha \\ ${ }^{1}$ Faculty of Fine and Applied Arts, \\ ${ }^{2}$ Faculty of Education, \\ ${ }^{3}$ Faculty of Humanities and Social Sciences, Khon Kaen University, 123 Mittraphap Road, \\ Nai Mueang Sub-District, Mueang District, 40002 Khon Kaen Province, Thailand
}

\begin{abstract}
A research study on the arts teacher's paradigm for arts competition of secondary level in Northeastern region is a qualitative research with purposes to study the history of arts competition of secondary level in Northeastern Thailand as well as to study the arts teacher's paradigms for arts competition of secondary education in Northeastern Thailand. For research methodology, target group used in the study and data collection consist of arts teachers in a group of schools in the Northeast. The sampling group is composed of the following: key informants, consisting of art scholars, freelance artists and arts judges; casual informants, consisting of 12 teachers who won special awarded from the arts competition in visual arts of secondary education in the Northeastern region as well as those people involved-secondary school students, school directors, parents, sponsor, art institutes and private sectors. Research tools include a field survey, structured interview as well as unstructured interview, participant observation and non-participant observation as well as group discussion. Data analysis is conducted by document study as well as field data collected from surveys, observation, interviews, group discussion collected from note taking and transcription of recorded audio. Collected data is classified, categorized and summarized, according to the studied issues and then the data is analyzed within a theoretical framework and create theoretical conclusions. The study findings indicated that the Northeastern arts competition is a result of those art institutes in the public and private sectors-institutes of arts competition under the Office of the Basic Education Commission, Ministry of Education, institutes of arts competition under the Office of the Higher Education Commission. It also includes the private sectors, companies in the Northeast that organize drawing competition for the visual arts at the secondary level. The drawing contest of each institute has variations in the arts competition with varying degrees and variations as it deems appropriate. For the arts teacher's paradigms for secondary level arts competition in the Northeastern region, the findings indicated that arts teacher's paradigm consists of concepts, values, perceptions and practice. Concepts of an arts teacher consists of; teaching activities through the camp process, promoting contest activities; promoting children's specialty in visual art and technology applied to art teaching and applying online lessons. Arts teacher's values include; giving opportunity to the children having a love for art, inspiration from teachers and art teaching experience. Perceptions of arts teachers includes; maturity of the children, individual differences, art principles. Practice of the arts teachers consists of; teaching by demonstration; teaching the basics of art; teaching with work processes; paradigm of 12 art teachers for arts competition in Northeastern. All the four paradigms must rely on the key elements-change, adaptation, application and reformation.
\end{abstract}

Key words: Paradigm, art contest organization, secondary school level, Northeastern region, reformation, reformation

\section{INTRODUCTION}

History of Thai education policy, a tool for the development of the country is evident that education provision is to respond to the needs of economic, political, social and cultural development. Development of Thai education curriculum from 1960, 1978, 1990, 2001 and 2008's revised edition, Ministry of Education, signifies the policy of youth development in the 21st century, focusing on the promotion of morality, loving the Thainess having analytical skills, creativity having skills in technology and working with others in the world society.

For the core curriculum of the basic education 2008, the arts learning group focuses on promoting creativity, imagination, art appreciation, aesthetics, values that

Corresponding Author: M. Napawan Purisa, Faculty of Fine and Applied Arts, Khon Kaen University, 123 Mittraphap Road, Nai Mueang Sub-District, Mueang District, 40002 Khon Kaen Province, Thailand 
affect the human life. Therefore, art activities can be applied to develop learners directly in the aspects of physical well-being, intelligence, emotions and society. It also leads to social and environmental development; encourages self-confidence and creativity; improves the arts learning processes, overviewing ability, observation in details, being able to discover their own potential. These are considered the basis for further study or career as the children will have responsibility, discipline and can work with others. Learning art can help the student to improve understanding about artistic skills, becoming knowledgeable about the concept of rationality, the artistic way, the history of the local wisdom and the cultural foundation. The students will have a self-discovery reflected by art, exploring the potential, personal interests, learning to practice, observing delicate things, leading to appreciation of the value of art as well as the surrounding, developing attitudes, self-concentration, personal tastes having processing skills, expression skills, creativity and encouragement of student's awareness of the role of arts in the society (Anonymous, 2003). According to the course that focuses on the concept of art in various dimensions, it results in the application of arts teaching, creating a movement or concept of promoting arts in various forms including arts and crafts competition and arts competition in the public and private sectors, empowering the organization of arts competition in various situations.

The popularity of the competition at the society levels has resulted in the popularity of the competition in children and youth with a system of competition that has been flourished for about two decades. The visual arts of children and youth have been expressed rather in forms of two-dimensional drawing or painting which are considered convenient for competition as well as convenient for the transportation in quantity, to the quality competition arenas, becoming a framework of competition with wins and losses. The way to teach arts is focused on using the influence or the teacher's formula with limited form, limited content, limited visual structure, limited tactics and limited use of colors. This tends to lead to organizing a training camp that has a pattern of the arts teachers in the province to have a particular way in art teaching, so, the children and youth perform the same quality for the whole class or the whole school. This is a problem for the visual art talents for the Thai children and youth who should be treated naturally or with diversity in characteristics.

Considering the arts teaching at secondary level, it is necessary to understand the aims of educational management for adolescents with unique behaviors. Classes that can meet the needs of all high school students who are teenagers is key to learning success. With art, the students who produce it will be like a valuable product, consisting of creativity, knowledge, virtue and humanity, to live together in a peaceful society (Wattanasin, 2003). Having arts competitions in the northeast, it is important for the secondary school teachers to submit their artwork of visual arts to art institutes of both public and private sectors. Teachers and students are interested in the prizes awarded by art academy, resulting in arts competition. Additionally in the aspect of competition management, each institute has different objectives, including the rules in the contest which are different as well. In terms of techniques, it is noteworthy what paradigms or concepts of teaching art the secondary school art teachers have for the preparation for arts competition in the Northeast held by various agencies.

The paradigm of art teachers is important to Thai education in the past and present. There is a change in the time system. The paradigm of art teachers at the secondary level for arts competition in the Northeast is very interesting. In this study, the researcher selects students in secondary school because of their readiness to study and create an artwork, suitable for arts competitions in various parts of the public and private sectors. Art institutes in the Northeastern region also play an important role for teachers and secondary school students in the Northeast to send their students to the visual arts competitions. What benefits and losses, the teachers, students and stakeholders would have what paradigms of arts teachers for teaching and learning activities to prepare for arts competition would be what development of art education to keep up with the modern world would be to make them truly understand about art, how to judge that students have knowledge of art or how effective a art teacher could be. The researcher therefore is interested in studying the history of the secondary arts competition in the Northeast as well as the arts teacher's paradigm for secondary level arts competition in the Northeastern region as a guideline for the development of teaching and learning activities and development of secondary school arts competition in the Northeast.

\section{Research objectives:}

- To study the history of arts competition of secondary level in the Northeast

- $\quad$ To study the paradigms of art teachers of secondary level arts competition in the Northeast

\section{Scope of research}

Content scope: In this study, content scope is to study the history of the arts competition of secondary level in the Northeast as well as art teacher's paradigms for secondary level arts competition in Northeastern Thailand.

Area scope: The main research areas are the secondary schools in the Northeast. For the Northeastern regional competition, it can be divided into 3 groups-the upper 
Northeast for 5 schools, the middle Northeast 2 schools and the lower Northeast 5 schools, totaling 12 schools. The awards are from arts contest of the major public and private painting contests in the Northeast.

\section{MATERIALS AND METHODS}

This research is mainly focused on target groups used in the study and data collection consist of secondary schools in the Northeastern provinces; the upper Northeast, the middle Northeast, the lower Northeast which arts teachers sent the visual arts to the arts competition at the provincial, regional and national levels being honored or awarded with prizes. Target groups are as follows:

Target group: From the target group above, the researcher selected the following research groups as in the following points:

- Key informant consists of art academics, freelance artists and artistic judges

- Casual informant consists of 12 arts teachers in the field of visual arts at secondary level in the Northeast

- General informant consists of secondary school students, school directors, parents, sponsors, art institutes and companies

Research tools: Researchers have designed and planned the tools used in the research that consist of field interview with structured interview and unstructured, participant observation and non-participant observation, as well as group discussion.

Data collection: The researcher collected the following data: documents and research studies related to the history of the institutes, paradigm of the arts teachers at secondary education in the Northeast by researching from government agencies, academic institutes, study of books, textbooks, research articles, dissertations, independent study, internet research and field data collection collected from the study areas by means of structured and unstructured interviews, participant and non-participant observation as well as group discussion.

Data analysis: The data achieved from the document study and data from the field are analyzed as follows; information from various studies is gathered for an in-depth study, field data collected from survey, observation, interviews, group discussion, note taking and transcription of recorded audio, classified, categorized and summarized according to the research topic. Information collected from papers, field data are compiled from the survey, then the data is analyzed, using theoretical framework, synthesized and generate data conclusions, according to the set-forth theory.

\section{RESULTS AND DISCUSSION}

This research is conducted to study the history of the secondary level arts competition in the Northeast as well as to study the paradigm of arts teachers for arts competition of secondary level in Northeastern Thailand. Study findings are as follows.

\section{History of the arts competition of secondary level in the Northeast}

Institutes for arts competition of secondary level in the Northeast: For schools under the office of elementary education which conduct arts education at lower secondary level and schools under the Office of Secondary Education in the Northeast, teachers send high school students who are talented in visual arts to participate in drawing contests at the arts institutes. There are a number of major art institutes in the Northeast as in Table 1.

Arts longa vita brevis drawing contest: The Ars Longa Vita Brevis drawing contest was first organized by Faculty of Education, Khon Kaen University in 1987. It has a history of art exhibitions organized on to celebrate the founding of the Faculty of Education and on Silpa Bhirasri day held every year. On the 29th year of the "Ars Longa Vita Brevis" drawing contest held in the year of 2016, there have been featured works of teachers, alumni and current members of Department of Art Education as well as student's drawings from primary and secondary schools throughout the Northeast. Each of the award-winning works is designed for the young people to freely give creative expression. Topics for the drawing contest are renewed every year to correspond with the flow of social change. The award-winning drawings are selected by assigned categories-excellence award,

Table 1: Briefed history of the institutes for arts competition in the Northeast

\begin{tabular}{ll}
\hline Institute's name & Original affiliation \\
\hline Arts Longa Vita Brevis & Faculty of Education, Khon Kaen University \\
"Bring Good Things to Life” by Toshiba & Toshiba Thailand Co., Ltd. \\
Esan Excellence Fair & OBEC, Ministry of Education \\
Drawing Contest of Tri Petch Isuzu Sales Co., Ltd. & Tri Petch Isuzu Sales Co., Ltd. \\
Yuvabadhana Art Contest & Yuvabadhana Foundation in cooperation with Silpakorn University \\
PTT art competition for Northeastern Youths & PTT Plc. in cooperation with Khon Kaen University \\
Imagination, Thai Literature Conservation Contest & In Touch Holdings Plc. \\
with InTouch project & \\
Toyota Dream Car Art Contest & Toyota Motor Thailand Co., Ltd. \\
\hline
\end{tabular}



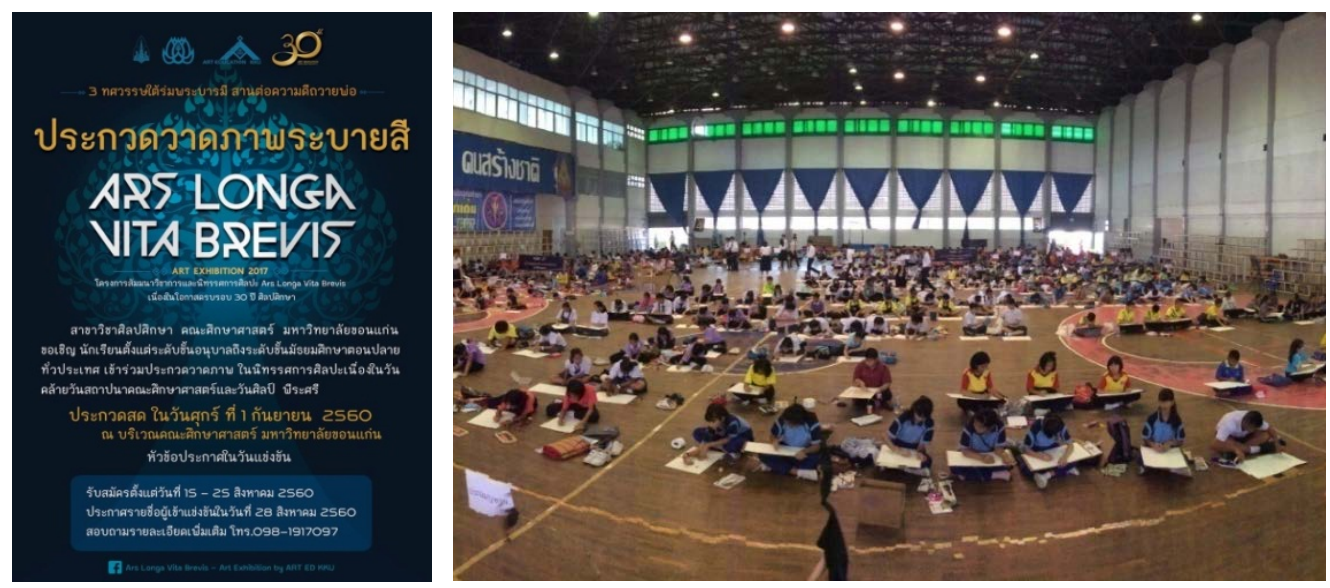

Fig. 1: The 30th Ars Longa Vita Brevis drawing contest

Outstanding Award and Creative Award. The students themselves, from kindergarten to high school level can use their imagination to convey the perspective of artwork. Assoc. Prof. Dr. Niyom Wongphongkham, Project Advisor, talks about the arts competition that it is held every year to stimulate the society to be active in art education promotion for the youth. It also provides opportunities for students from all schools across the country, especially, students in the Northeast, to participate in the competition. Contestants range from kindergarten to secondary level feel free to submit entries to the competition as they are inspired and have the consciousness they cultivated in or perceived themselves to convey through drawings. This can help to express themselves to adults and the society as it represents pure thoughts with no makeup, only the children's imagination of their own (Anonymous, 2007). It can be seen that the drawing contest, held yearly on the day of the founding of the Faculty of Education and on Silpa Bhirasri day by Department of Art Education, Faculty of Education, plays an important role for the arts teachers of secondary level in the Northeast to pay attention to and to submit their entries to the drawing competition continuously (Fig. 1).

\section{"Bring Good Things to Life" art contest by Toshiba} Thailand: Arts contest titled "Bring Good Things to Life" by Toshiba Thailand has been first launched in 1988. In 2017, marking the 29th year, the arts competition program is sponsored by the group of companies of Toshiba Thailand, to organize a drawing contest on creative arts in visual arts with aims to develop the national arts to be widespread and socially acceptable. In addition, it is considered another way of minds development of a person, the development of creativity and the development of national sustainable growth. There are five types of judging: kindergarten and junior elementary school, senior elementary school, lower secondary school, high school and vocational education and higher education and public individuals. The contest also includes the "Toshiba Art Street Show" activity for the art enthusiasts (Toshiba, 2017).

It is evident that the group of companies of Toshiba Thailand recognizes the role of Corporate Social Responsibility (CSR) titled "Bring Good Things to Life" that the company brought into the society. It has been held for 25 years now and will be held every year to give students and the general public a chance to experience and appreciate the art of social development. Arts teachers at high schools in the Northeast are interested in submitting artworks as well as the contestants are continuously rewarded as they regard the importance of art for the students and youth in the Northeast (Fig. 2).

Arts competition at Esan Excellence Fair, office of the basic education, Ministry of Education: Student's Excellence Fair has been started in 1912 during the reign of King Rama VI which was in the core curriculum of basic education in the year of 2001. The purpose was to encourage the children in those days to pay attention to practice arts of crafting. Student's Excellence Fair has been organized continuously, except for some skips when the country's situation was serious as well as there have been changes in the name several times. Student's Excellence Fair is known to the public from the past to present, noticing from the number of 67 times the event has been held. The first Student's Excellence Fair was held on January 3, 1912 at Suankularb Wittayalai School, by courtesy of Chaophraya Phrasadet Surentharathibodi (MR. Pia Malakul), Minister of Public Instruction, since, its inception in 1915 until the 12th in 1923. After the 12th event, there have been a long skip for 25 years because at that time, the country was in a worrying state when King Rama VI died in 1925 as well as a change of government rule by Khana Ratsadon (People's Party). The 13th Student's Excellence Fair was organized by Ministry of 
(a)

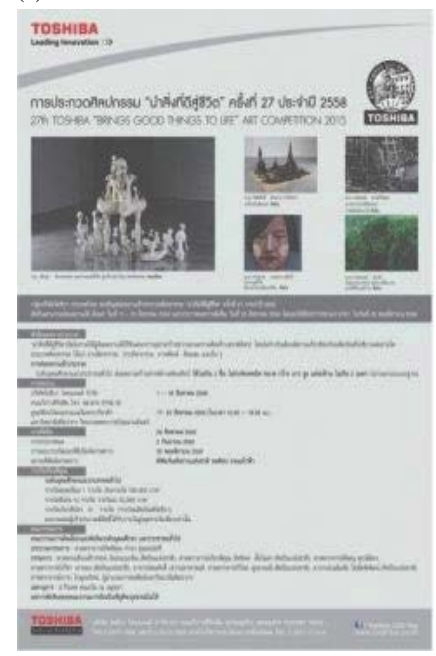

(b)

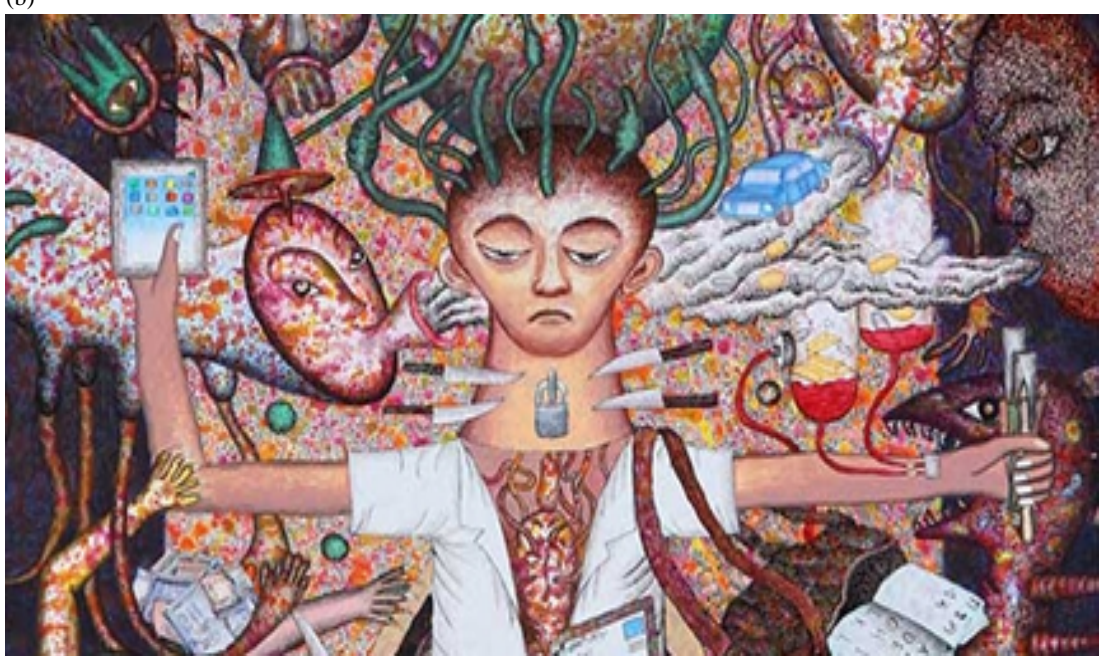

Fig. 2 (a-b): The 27th "Bring Good Things to Life” art contest

(a)

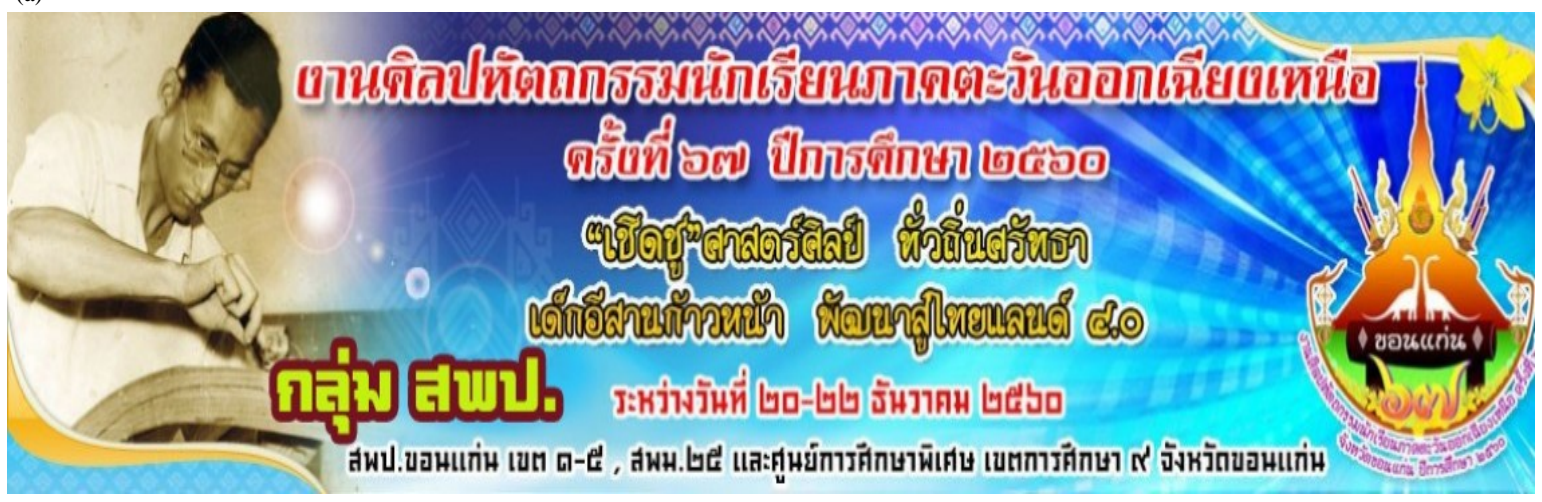

(b)

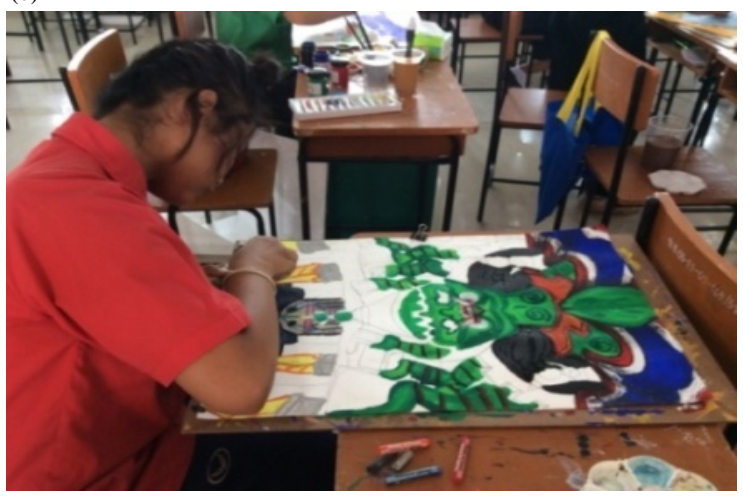

(c)

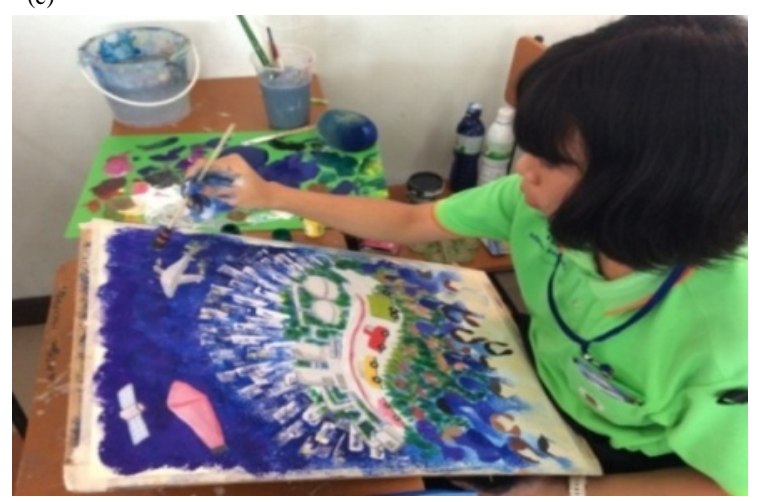

Fig. 3 (a-c): A drawing contest held at the 67th Esan Excellence Fair

Education on December 8-12, 1949 at Suankularb Wittayalai School. The 13th to 33rd events were organized centrally only in Bangkok (Fig. 3).

Student's Excellence Fair was first organized in the Northeast in the 44th event in 1991 which was a special event celebrating the 100th anniversary of Ministry of
Education and it was a great change that the event has been started to spread throughout the country to open opportunity for the regional youths to have the opportunity to participate in the event titled "Student's Excellence Fair celebrating 100 years of Ministry of Education”. All departments in the Ministry of Education 
are invited to organize the event and it is organized in the five regions for the first time on November 28-30, 1991 at Educational Zone 11 of Nakhon Ratchasima. Every year, since, then the Student's Excellence Fair by Ministry of Education has been organized at a different venue. This is a great way to promote the major provinces of educational agencies of Ministry of Education in the areas of primary education and secondary education. Since, the academic year 1992 onwards, the event has been divided into 4 regions, named "Student's Excellence Fair". The 36th event held in 1973, then Ministry of Education has not held any events, since, the year 1973-1982 when the event has been skipped for a period of 10 years. In 1983-1984, Student's Excellence Fair has been restored by being organized in conjunction with the National Children's day events. The 37th event in 1985 was held at Suan Ambhorn and Department of Vocational Education has fully involved and used the name "Excellence Fair and Vocational Education '85" to emphasis the theme "Career Education". The organization of Student's Excellence Fair has been changed again when the 56th competition was held in the academic year 2004, there were events in all the 4 regions. After that, the event ceased for 3 years after the reform of education and the dissolution of many educational departments to become the Office of the Basic Education Commission, consisting of the Office of National Primary Education Commission, Department of General Education and Department of Academic Affairs. In 2005, Office of the Permanent Secretary, Ministry of Education, handed over the organization of Student's Excellence Fair to the Office of the Basic Education Commission to be responsible for organizing the event. The 57th fair, organized in the academic year 2007 was restored to be held in the four regions again. There have been changes in venue for the organization of Esan Excellence Fair of the Northeast every year; marking the 67th event at present in 2017 where Esan Excellence Fair is held at the Northeastern level in Khon Kaen province.

Drawing contest of Tri Petch Isuzu Sales Co., Ltd.: Poster drawing contest with a project slogan "Isuzu Youth Relations" was first held in 1992. Having been organized continuously for 25 years, the competition program is open for the Thai youths to express their creativity through art by drawing a poster with a slogan of which the themed topic is beneficial to society on that particular occasion, opening an opportunity for the Thai youth to use the artistic ability, like a slogan "Isuzu's commitment to the Thai youths is not far beyond reach.” Tri Petch Isuzu Sales Co., Ltd. in conjunction with the Sports Authority of Thailand and the Office of the Basic Education Commission, Ministry of Education, organized press release for the opening of "Isuzu Youth Relations 2016" to enable the youths at high school level across the country to convey the creative imagination to be awarded with "Young Artist of the Year" award with a special prize "Isuzu Takes You to Japan" with plaques and scholarships. The contest organization is different every year; competition topic and theme are altered every year in order to keep up with the country's situations. Mr. Toshiyaki Maekawa, managing director of Tri Petch Isuzu Sales Co., Ltd., said that the competition aims to communicate value and the importance of sport in Thai youth which becomes theme for a poster drawing contest on a topic "Sports Value for Life" in the "Isuzu Youth Relations 2016" to cultivate good awareness and to reflect the benefits of sport in various aspects through art expression as a link; that is the main purpose for each year's competition that students or young people need to express themselves creatively (Fig. 4).

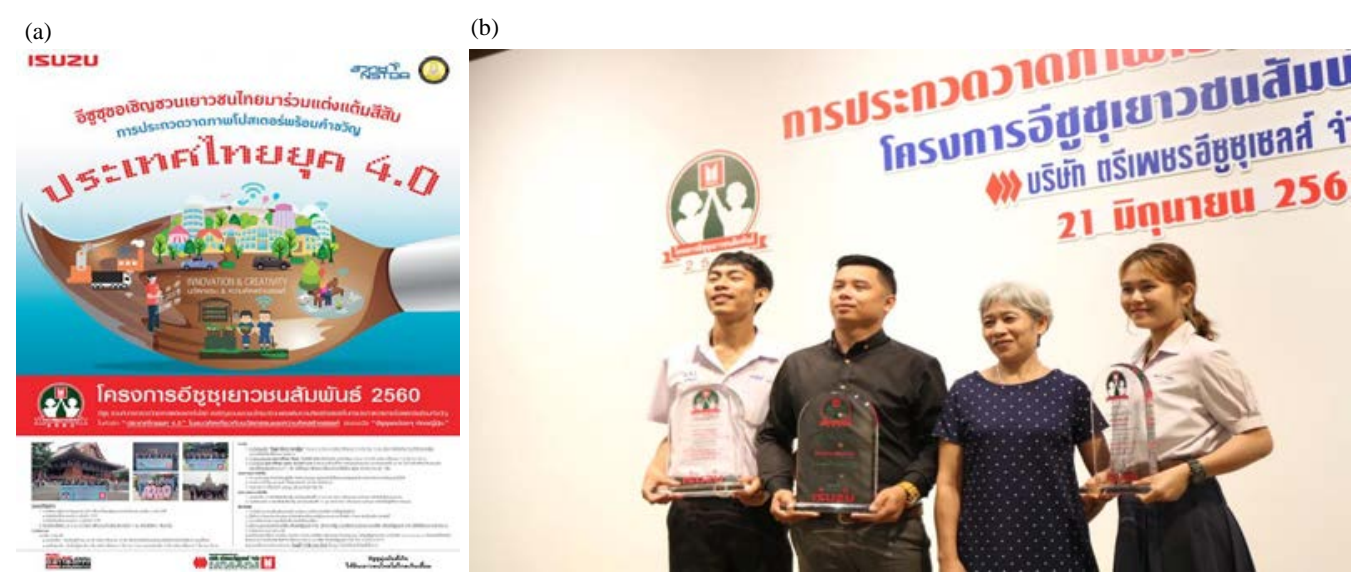

Fig. 4(a-b): Drawing contest of Tri Petch Isuzu Sales Co., Ltd., 2017 
The "Poster Drawing Contest with a Slogan" in "Isuzu Youth Relations 2016" is organized for the youths who are studying in junior high school, under 15 years of age and senior high school under 18 years. The 2 teams of 2 contestants each can participate in the competition. The high school teachers in the Northeastern region are interested in sending their students to participate in this contest very well as they see the importance of the event's purposes. Each of the team members must be in the same education level and from the same school (1 person can only be affiliated with one team). Contestants will enter the qualifying rounds to qualify for the final which is a live drawing competition within assigned time and with an unknown topic. A team of outstanding creativity and excellence will receive awards, according to the competition.

Yuvabadhana art contest, Yuvabadhana Foundation: Yuvabadhana art contest by Yuvabadhana Foundation has been launched with aims to promote the development of the artistic initiative. The first Yuvabadhana art contest was organized in 1994 and has continued its activity for 23 years in collaboration with the Faculty of Painting Sculpture and Graphic Arts, Silpakorn University. The Yuvabadhana art contest aims to open an opportunity for the young people to develop skills outside the classroom being creative, imagining and cultivating good values in creating works of art. Contest topics vary from year to year but focus on the youth to see their own value and to know of the benefits for the others. The contest will be held in the first semester of every academic year. After the contest, the Foundation will select some of the award-winning photographs to be printed as new year greeting cards and calendars for sale to customers and interested people. Income will be for the publication of a book of knowledge under a project titled "Yuvabadhana literature" to give to students in the impoverished area across the country. Those who are interested can have the books donated as part-time reading books for students at various schools. It is one of the projects under the Yuvabadhana Foundation with goal to enable the children to discover their potential and talents which is important that children grow in quality and are proud of themselves. Yuvabadhana Foundation then has organized the Yuvabadhana art contest and the Yuvabadhana literature contest annually to promote the artistic and literary talents of children. Arts and literature are regarded important tools in refining, cultivating morals and ethics for children. Giving them support is the power that drives the secondary school children to work creatively and discover their potential within (Yuvabadhana Foundation, 2016).

The Yuvabadhana art contest is held every year. Secondary school arts teachers in the Northeast show great interest in submitting entries to the contest continuously. This can be noticed from the award s given to the arts teachers in the Northeast as the prizes are attractive and of great pride for the award-winning students. It is one of the most important institutes recognized for arts competition (Fig. 5). (a)

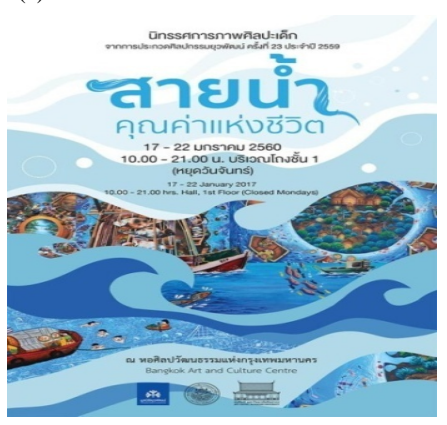

(b)

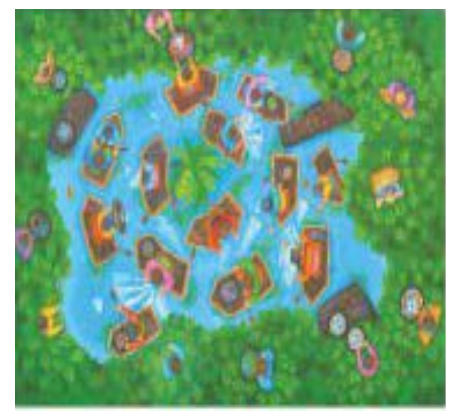

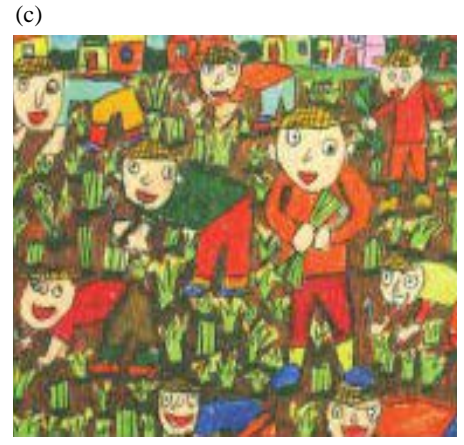

Fig. 5(a-c): The 23rd Yuvabadhana Art Contest, 2010 
PTT arts competition for Northeastern youths: The PTT arts competition was first held in 1986. The private institute organizes the arts competition every year. The PTT art competition are normally held during the same period as the contest held by Philips Thailand and Toshiba Thailand Co., Ltd. which shows the broaden scope of sponsors for the art industry. Young people then can have more open spaces to present a variety of artworks as well as the more selective contents and support that has extended more to the competition of the children and youth which will be the basis for the bigger arenas for the future of arts of the nation. These children can experience in the private contest arena to compete internationally. The PTT arts competition has been for 32 years now. Starting in 1949, the national arts competition began with the National Exhibition of Art by Professor Silpa Bhirasri. The highlight of the stage of the PTT arts competition is the collaboration of the Art Gallery of Silpakorn University that expanded the scope of the exhibition to remote regions. This is to give the children, the youth and people far from Bangkok to have a chance to experience the true art, to appreciate the value in arts. To achieve this, a mobile exhibition held by PTT called "PTT Road Arts Competition" has been initiated and the organizers also added another form of art contests-"PTT Provincial Arts Competition” in 2005 by holding a contest of live painting in a time limit. A team of three but not exceed 5 contestants can join the competition, so that, there is a systematic division of functions. Awarding will be right at the competition. The regional schools will select a team of students to compete in the competition. The regional mobile competition is a pattern of challenging mobile contests, causing the awakening of the arts at schools that are far away. Chiang Mai is selected the center of the North in cooperation with the Faculty of Fine Arts, Chiang Mai University, the art gallery is used for the competition. For the Northeastern competition, it is arranged at Art Gallery of Faculty of Fine and Applied Arts, Khon Kaen University; while Thaksin University in Songkhla province is venue for the southern competition. In addition, the PTT arts exhibition will be showcasing the award-winning works at all regional levels to be displayed at special exhibitions at the exhibition hall of PTT Head Office for the PTT employees and visitors to have a chance to admire the arts of PTT (Supanimit, 2010) (Fig. 6).

For the drawing contest, PTT Public Company Limited (PTT) in cooperation with Faculty of Fine and Applied Arts, Khon Kaen University, organizes a drawing contest for students from kindergarten to secondary school and vocational school in the Northeast. It was held for the 13th time in 2018 at the Faculty of Fine and Applied Arts, Khon Kaen University. Representatives from both sides, PTT Public Company Limited and Khon Kaen University have been cooperating well in the process of organizing the event. Each drawing contest will have the topic of the contest changed every time to keep up with the times and social changes developing every year. It is a major secondary art education institute in the Northeast. Secondary school arts teachers in the Northeast show great interest in submitting students to participate in the arts contest in large numbers every year as the awards are of interest to the students and teachers and pride for those award winners. It is an institute of arts contest with students entering the contest a lot every year.

Arts competition in the "Imagination, Thai Literature Conservation Contest with InTouch” project: Being arranged by InTouch Holdings Plc., the arts competition of the "Imagination, Thai Literature Conservation Contest with InTouch” project started its first contest, since, 2006, marking the 11th year in 2017. The competition
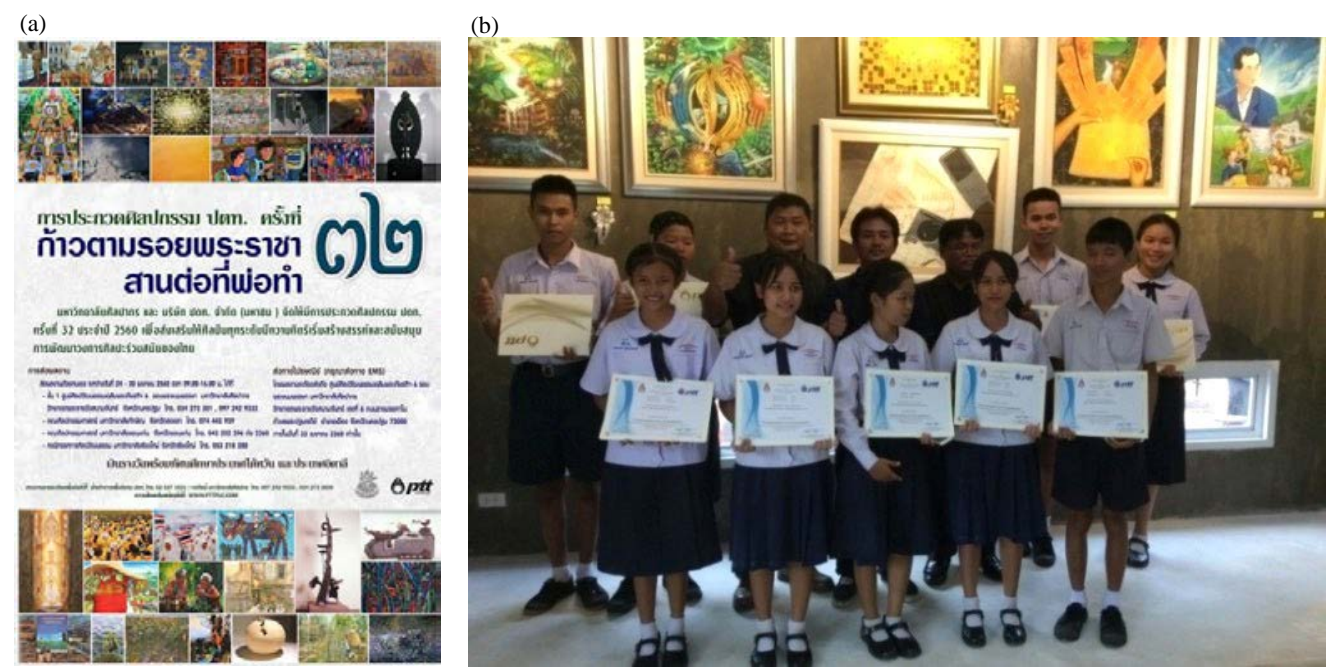

Fig. 6 (a-b): The 12th PTT arts competition for Northeastern youths, 2017 


\section{J. Eng. Applied Sci., 15 (6): 1359-1376, 2020}

(a)

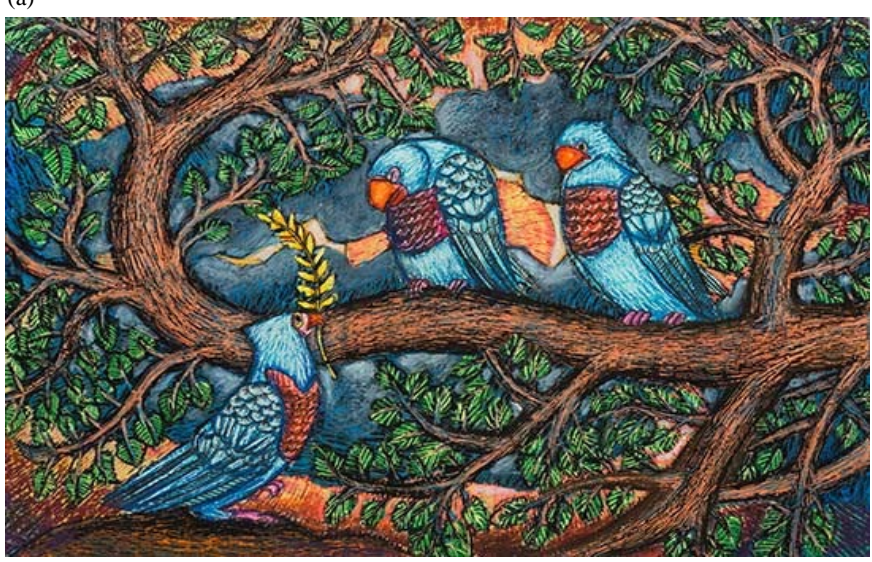

(b)

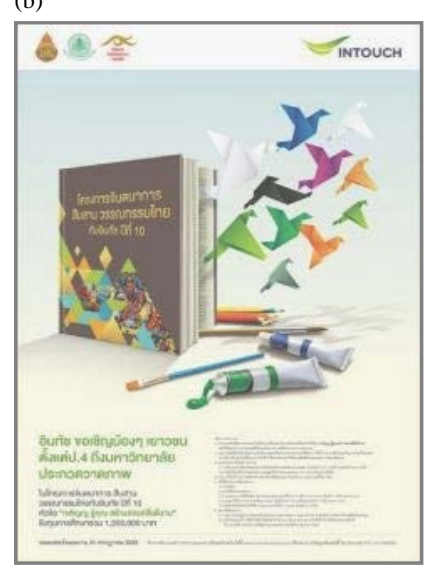

Fig. 7 (a-b): Arts competition of a project called “Imagination, Thai Literature Conservation Contest with InTouch”

program is to encourage the Thai youth to love reading be aware of the Thai language and literature preservation Thailand's valuable cultural heritage, to remain, using imagination to convey what is read to be a drawing, according to their own imagination. InTouch Holdings Public Company Limited is another major competition institute in the Northeast that opens for the application to the contest. Contestants can be any Thai youth across the country young people studying in elementary school in junior or senior high school or equivalent and those studying in higher education. For arts competition of InTouch Holdings Public Company Limited, the contest topic is in relation with Thai literature as it corresponds to the theme "Imagination, Thai Literature Conservation Contest" to encourage Thai youth to join the campaign, promote and be aware of the conservation of Thai language and literature through verse in the form of prose and poetry, using the imagination to convey the literary read out as a painting of their own imagination, creating great work of art to the contest which is kind of work submission competition. One of the reputed committees is Sangkhom Thongmee, an art teacher who pioneered the arts in the Northeast, a master teacher in the art and arts competition in the early days of high schools in the Northeast. He plays an important role in the arts competition and is a judging panel for many art institutes as well as Professor Chalermchai Kositpipat, one of the judges who has commented, "The works of art submitted to the contest each year are with new techniques and a new way of work presentation with new artistic creations that need to be trained and practiced. Therefore, those who want to be the best need to be creative have good techniques and good workmanship". This makes the teachers in elementary and secondary schools in the Northeast become more interested in submitting entries to the contest continuously (Imagination, Thai Literature Conservation Contest with InTouch Project (Anonymous, 2016) (Fig. 7).
Arts competition of Toyota dream car art contest: Arts competition of Toyota Motor Thailand Co., Ltd., pursuing the dream and building imagination for the Thai youth through the activities of drawing contest on a topic “Toyota Dream Car Art Contest 2018” which is held for the 8th year. Mr. Wutikorn Suriyachantanon, Executive Vice President of Toyota Motor Thailand Co., Ltd., said about "Toyota Dream Car Art Contest" that it is a global drawing and painting contest organized with aims to raise the capacity of the Thai youth, along with promoting the learning society. Toyota aims to give the young people an opportunity to express their creativity and imagination through the use of art as a medium in the drawing and painting under a topic "Dream Car" as well as to encourage the new generation of young people to experience the technology and automotive innovation of the future. It is also a channel to create opportunities and support the ability of Thai youth to progress to the international competition programs. Application and entries submitted to the contest should show the quality of creativity, artistic skills, presentation method and the uniqueness of Thai culture outstandingly and beautifully.

Toyota has also focused on lifting and enhancing the skills of the youth across the country through activities, workshops and the development of artistic skills for students and teachers. Basic knowledge of drawing under the topic of "Dream Car" as well as organizing activities to educate local students which is the key to creating quality work, including support from the Ministry of Education in project publicity. This resulted in the successful implementation of the project. Winner of the 1st prize in each age category will be awarded a trophy from HRH princess Maha Chakri Sirindhorn. The winner of the national contest will receive a scholarship with a plaque from Toyota Motor Thailand Co., Ltd. and a certificate by Ministry of Education. They can also be representatives from Thailand to participate in the 
(a)

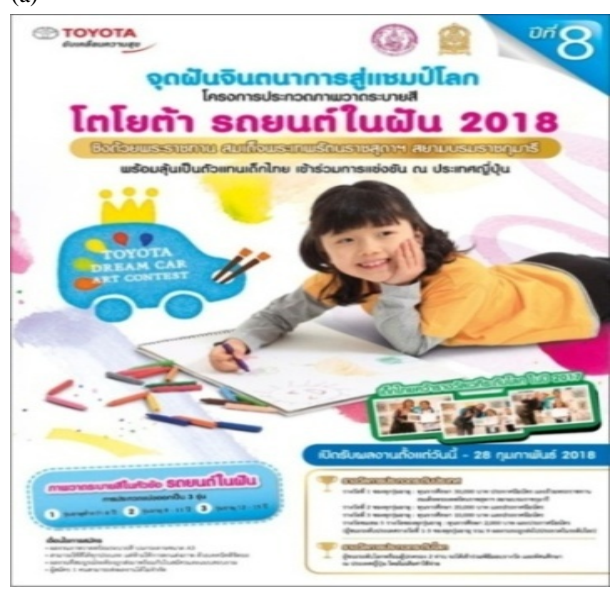

(b)

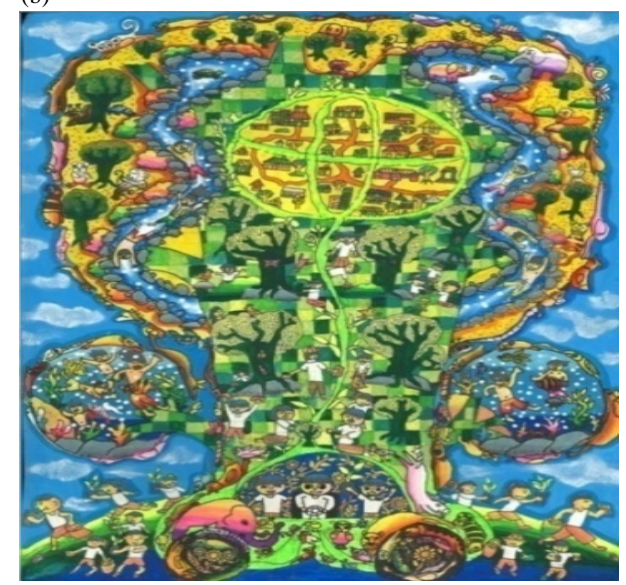

Fig. 8 (a-b): Arts competition of Toyota Motor Thailand Co., Ltd., 3rd prize

international competition-Toyota Dream Car Art Contest in Japan. The announcement of the results of the global contest is in August, 2018. This project was a great success that Thailand has won up to 28 prizes from the Toyota Dream Car Art Contest, competing contestants from more than 80 countries. This demonstrates the potential of talented Thai youth that can compete at the world competition, bringing back pride to the nation (Fig. 8). Mr. Pathanin Samana from Ban Huay Sai Ngua School, Nongkhai province in the title of "Vehicle of Life".

As a result of the study, the history of arts institutes for arts competition of secondary level in the Northeast, categorized by agencies affiliated, the 8 institutes are classified as follows:

- 1 institute of government sector-Student's Excellence Fair of the Office of the Basic Education, Ministry of Education

- 1 institute of company in cooperation with university-PTT Arts Competition for Northeastern youths in cooperation with Faculty of Fine and Applied Arts, Khon Kaen University

- 1 institute of university agency: Arts Longa Vita Brevis. Faculty of Education, Khon Kaen University

- 4 institutes of private sector-"Bring Good Things to Life" by Toshiba, drawing contest of Tri Petch Isuzu Sales Co., Ltd., imagination, Thai literature conservation contest with InTouch Project, Toyota Dream Car Art Contest

- 1 institute of foundation in cooperation with university-Yuvabadhana foundation in cooperation with Silpakorn University

It is evident that private companies are major arts institutes in the Northeastern region to play a role as well as to promote the public relations of the company. Teachers of visual arts teachers in secondary schools in the Northeastern region are interested in sending a number of students to compete in the arts competitions. The results of the study of time period of the contest, categorised by competition years of the 8 institutes, sorted chronologically are indicated in the following points:

- $\quad$ Arts Longa Vita Brevis Art Contest, 1987

- Art Contest "Bring Good Things to Life" Toshiba Thailand, 1988

- $\quad$ Art Contest at Esan Excellence Fair, 1991

- Drawing Contest of Tri Petch Isuzu Sales Co., Ltd., 1992

- Yuvabadhana Art Contest, 1994

- $\quad$ PTT Arts Competition for Northeastern Youths, 2005

- Arts Competition of "Imagination, Thai Literature Conservation Contest with InTouch Project”, 2006

- Arts Competition of Toyota Dream Car Art Contest, 2011

It can be seen that for the period and years of the arts competition in the Northeast of Thailand, drawing contest in the anniversary celebration of Faculty of Education and the Silpa Bhirasri day was in 1987, close to a contest held in 1988-"Bring Good Things to Life" by Toshiba Thailand. Esan Excellence Fair was first held in the Northeast in 1991 whereas the first student's excellence fair began in 1912 during the reign of King Rama VI. Student's Excellence Fair in the Northeast was first organized by the government agency-the Office of the Basic Education, Ministry of Education. This can be concluded that the Ministry of Education sees the importance of promoting youth at the regional level. The competition in the Northeastern region was established in 1991, close to the drawing contest of Tri Petch Isuzu Sales Co., Ltd. that was established in 1992 and the Yuvabadhana Art Contest held in 1994. The PTT arts competition for Northeastern Youths was first held in 2005, close to the arts competition of a project called "Imagination, Thai 
Literature Conservation Contest with InTouch" held in the year of 2006 while arts competition of Toyota Motor Thailand Co., Ltd. was held in 2011 which is the latest institute for art competition. Anyway, the work of art is distinctive and outstanding, making teachers from secondary schools in the Northeast interested in submitting a large number of visual art works.

Arts competition patterns: In the case study of art competition in high school in the Northeast was consisted of arts competition purpose, competitor categorization, contest topic selection, scale of works, materials and techniques, rewarding, criteria of score assessment (Table 2).

As a result of study, the purposes, principles, reasons include the patterns of art competition of each institute are similar or little different. The general purposes are to realize the important of quality development for youth to be flourish by using art as a way to express the own creativity, to be aware of responsibility of nature art and environment for children and to expand the art works of Thai youth in Thailand and international. For the compititors, the art institutes use the age and education level as a criteria e.g., PTT art competition, "Bring Good Things to Life" by Toshiba, Thailand. There are 2 contest topics which are the art institute assigned the topic or content such as PTT art competition and the art institute unassigned the topic but the content concern about the youth's experiences e.g., the rountine, tradition, culture, future world, environment etc. Theart works are mostly $2 \mathrm{D}$ such as painting.

As we can see in the art topic selection for youth activities is considerably important as Wirun Tangcharoen said that "the topic selection which children express

Table 2: Table of summary of arts competition patterns of the Northeastern arts institutes

\begin{tabular}{|c|c|c|c|c|c|c|c|}
\hline Name of institute & Purposes & Competitors & Contest topics & $\begin{array}{c}\text { Scale } \\
\text { of works }\end{array}$ & $\begin{array}{c}\text { Materials } \\
\text { and techniques }\end{array}$ & Rewards & $\begin{array}{c}\text { Criteria of } \\
\text { score assessment }\end{array}$ \\
\hline $\begin{array}{l}\text { ARTS LONGA } \\
\text { VITA BREVIS }\end{array}$ & $\begin{array}{l}\text { The activity correspond to } \\
\text { the important day which is the } \\
\text { day of the founding of the } \\
\text { Faculty of Education and on } \\
\text { Silpa Bhirasri day }\end{array}$ & $\begin{array}{l}\text { Kindergarten } \\
\text { Primary school } \\
\text { (Grade 1-3) } \\
\text { Primary school } \\
\text { (Grade 4-6) } \\
\text { Junior high school } \\
\text { Senior high school }\end{array}$ & $\begin{array}{l}\text { Topics for the } \\
\text { contest are } \\
\text { renewed every } \\
\text { year to correspond } \\
\text { with the flow of } \\
\text { social change }\end{array}$ & $38 \times 56 \mathrm{~cm}$ & $\begin{array}{l}\text { Freestyle } \\
\text { techniques }\end{array}$ & $\begin{array}{l}\text { Winner award } \\
\text { First runner-upaward } \\
\text { Honorable mention } \\
\text { award }\end{array}$ & $\begin{array}{l}\text { Quality works } \\
\text { The content } \\
\text { corresponding to } \\
\text { the contest topics } \\
\text { Creativity }\end{array}$ \\
\hline $\begin{array}{l}\text { "Bring Good Things } \\
\text { to Life" by Toshiba }\end{array}$ & $\begin{array}{l}\text { Develop the national arts to } \\
\text { be widespread and socially } \\
\text { acceptable }\end{array}$ & $\begin{array}{l}\text { Kindergarten, primary } \\
\text { school, secondary school } \\
\text { and vocational education } \\
\text { University and } \\
\text { general people }\end{array}$ & $\begin{array}{l}\text { Topics for the contest } \\
\text { are renewed every year } \\
\text { to correspond with the } \\
\text { flow of social change }\end{array}$ & $\begin{array}{l}15 \times 22 \\
\text { inches }\end{array}$ & $\begin{array}{l}\text { Freestyle } \\
\text { techniques }\end{array}$ & $\begin{array}{l}\text { Excellence award and a } \\
\text { trophy from HRH Princess } \\
\text { Maha Chakri Sirindhorn } \\
\text { Outstanding award and } \\
\text { certificate } \\
\text { Special award and } \\
\text { certificate }\end{array}$ & $\begin{array}{l}\text { Quality works } \\
\text { Completely } \\
\text { Present the issue } \\
\text { corresponding to } \\
\text { assigned topics } \\
\text { Outstanding } \\
\text { works }\end{array}$ \\
\hline Esan Excellence Fair & $\begin{array}{l}\text { To encourage the children } \\
\text { in regional to pay attention to } \\
\text { practice arts of crafting }\end{array}$ & $\begin{array}{l}\text { Kindergarten } \\
\text { Primary school } \\
\text { (Grade 1-3) } \\
\text { Primary school } \\
\text { (Grade 4-6) } \\
\text { Junior high school } \\
\text { (Grade1-3) } \\
\text { Senior high school } \\
\text { (Grade 4-6) }\end{array}$ & $\begin{array}{l}\text { Topics for the contest } \\
\text { are renewed every } \\
\text { year to correspond } \\
\text { with the flow of } \\
\text { social change }\end{array}$ & $\begin{array}{l}5 \times 22 \\
\text { inches }\end{array}$ & $\begin{array}{l}\text { Junior high } \\
\text { school (Grade1-3) } \\
\text { use poster color } \\
\text { or acrylic color } \\
\text { Senior high school } \\
\text { (Grade 4-6) use } \\
\text { water color } \\
\text { in some activities } \\
\text { and able } \\
\text { to use more } \\
\text { color types }\end{array}$ & $\begin{array}{l}\text { Score } 80-100 \text { points } \\
\text { get gold medal } \\
\text { Score } 70-78 \text { points } \\
\text { get silver medal } \\
\text { Score } 60-69 \text { points } \\
\text { get copper medal } \\
\text { Score under } 60 \text { points } \\
\text { get certificate }\end{array}$ & $\begin{array}{l}\text { Creativity } \\
\text { Techniques } \\
\text { using } \\
\text { Fineness and } \\
\text { aesthetics of } \\
\text { works } \\
\text { Correspondence } \\
\text { of works and } \\
\text { assigned topics } \\
\text { Completeness } \\
\text { and composition } \\
\text { of work }\end{array}$ \\
\hline $\begin{array}{l}\text { Drawing contest } \\
\text { of Tri Petch Isuzu } \\
\text { Sales Co., Ltd. }\end{array}$ & $\begin{array}{l}\text { Opening for the Thai youths } \\
\text { to express their creativity } \\
\text { through art by drawing a } \\
\text { poster with a slogan of } \\
\text { which the themed topic is } \\
\text { beneficial to society on } \\
\text { that particular occasion }\end{array}$ & $\begin{array}{l}\text { Junior high school } \\
\text { (Not over } 15 \text { years old) } \\
\text { Senior high school } \\
\text { (Not over } 18 \text { years old) }\end{array}$ & $\begin{array}{l}\text { Competition topic and } \\
\text { theme are altered every } \\
\text { year in order to keep up } \\
\text { with the country's } \\
\text { situations }\end{array}$ & $\begin{array}{l}11^{1 / 2} \text { inches } \\
16^{1 / 2} \text { inches } \\
\text { (A3) }\end{array}$ & $\begin{array}{l}\text { Freestyle } \\
\text { techniques }\end{array}$ & $\begin{array}{l}\text { Winner award with a } \\
\text { special prize "Isuzu Takes } \\
\text { You to Japan" and honor } \\
\text { trophy } \\
\text { First runner-up award } \\
\text { with scholarship and honor } \\
\text { trophy } \\
\text { Special award and } \\
\text { scholarship }\end{array}$ & $\begin{array}{l}\text { Quality works } \\
\text { The content } \\
\text { corresponding to } \\
\text { the contest topics } \\
\text { Creativity }\end{array}$ \\
\hline $\begin{array}{l}\text { Yuvabadhana } \\
\text { Art Contest }\end{array}$ & $\begin{array}{l}\text { To open an opportunity } \\
\text { for the young people to } \\
\text { develop skills outside the } \\
\text { classroom, being creative, } \\
\text { imagining and cultivating } \\
\text { good values in creating } \\
\text { works of art }\end{array}$ & $\begin{array}{l}\text { Primary school } \\
\text { (Grade 1-3) } \\
\text { Primary school } \\
\text { (Grade 4-6) } \\
\text { Junior high school } \\
\text { (Grade1-3) } \\
\text { Senior high school } \\
\text { (Grade 4-6) }\end{array}$ & $\begin{array}{l}\text { Contest topics vary } \\
\text { from year to year but } \\
\text { focus on the youth to } \\
\text { see their own value } \\
\text { and to know of the } \\
\text { benefits for the } \\
\text { others }\end{array}$ & $15 \times 22$ inches & $\begin{array}{l}\text { Creative visual } \\
\text { arts by paper } \\
\text { drawing and able } \\
\text { to use drawing } \\
\text { and painting } \\
\text { techniques freely }\end{array}$ & $\begin{array}{l}\text { Every winner will get } \\
\text { honor certificate }\end{array}$ & $\begin{array}{l}\text { Quality works } \\
\text { The content } \\
\text { corresponding to } \\
\text { the contest topics } \\
\text { Creativity }\end{array}$ \\
\hline $\begin{array}{l}\text { PTT art competition } \\
\text { for Northeastern } \\
\text { youths }\end{array}$ & $\begin{array}{l}\text { To support Northeastern } \\
\text { youths to practice skills in } \\
\text { valuable art creativity }\end{array}$ & $\begin{array}{l}\text { Kindergarten } \\
\text { Primary school } \\
\text { (Grade 1-3) } \\
\text { Primary school } \\
\text { (Grade 4-6) } \\
\text { Junior high school } \\
\text { (Grade1-3) } \\
\text { Senior high school } \\
\text { (Grade 4-6) and } \\
\text { vocational education }\end{array}$ & $\begin{array}{l}\text { Each drawing contest } \\
\text { will have the topic of } \\
\text { the contest changed } \\
\text { every time to keep up } \\
\text { with the times and } \\
\text { social changes } \\
\text { developing every year }\end{array}$ & $60 \times 80 \mathrm{~cm}$ & $\begin{array}{l}\text { Using colored } \\
\text { pencil, water } \\
\text { color, poster } \\
\text { color, pastel } \\
\text { color, crayon } \\
\text { color and acrylic } \\
\text { color techniques }\end{array}$ & $\begin{array}{l}\text { Excellence award, } \\
\text { outstanding award and } \\
\text { honor mention award }\end{array}$ & $\begin{array}{l}\text { Quality works } \\
\text { The content } \\
\text { corresponding to } \\
\text { the contest topics } \\
\text { Creativity }\end{array}$ \\
\hline $\begin{array}{l}\text { Imagination, } \\
\text { Thai literature } \\
\text { conservation contest } \\
\text { with intouch project }\end{array}$ & $\begin{array}{l}\text { The aims of contest } \\
\text { change every time to } \\
\text { keep up with the times } \\
\text { and social changes } \\
\text { developing every year }\end{array}$ & $\begin{array}{l}\text { Primary school } \\
\text { (Grade 4-6) } \\
\text { Secondary schoolor } \\
\text { equivalent } \\
\text { University }\end{array}$ & $\begin{array}{l}\text { The contest topic is in } \\
\text { relation with Thai } \\
\text { literature as it } \\
\text { corresponds to the } \\
\text { theme "Imagination, } \\
\text { Thai literature }\end{array}$ & $\begin{array}{l}12 \times 16 \\
\text { inches } \\
\text { University } \\
\text { size } \\
16.5 \times 23.4 \\
\text { inches } \\
\end{array}$ & $\begin{array}{l}\text { Able to use } \\
\text { drawing } \\
\text { techniques and } \\
\text { freestyle paintings } \\
\text { Sketching } \\
\text { techniques or } \\
\end{array}$ & $\begin{array}{l}\text { Trophy from HRH } \\
\text { Princess } \\
\text { Maha Chakri Sirindhorn } \\
\text { and scholarship include } \\
\text { special award for youth }\end{array}$ & $\begin{array}{l}\text { The meaning of } \\
\text { work correspond } \\
\text { to assigned topic } \\
\text { obviously }\end{array}$ \\
\hline
\end{tabular}


J. Eng. Applied Sci., 15 (6): 1359-1376, 2020

\begin{tabular}{|c|c|c|c|c|c|c|c|}
\hline Name of institute & Purposes & Competitors & Contest topics & $\begin{array}{c}\text { Scale } \\
\text { of works }\end{array}$ & $\begin{array}{c}\text { Materials } \\
\text { and techniques }\end{array}$ & Rewards & $\begin{array}{c}\text { Criteria of } \\
\text { score assessment }\end{array}$ \\
\hline & & & $\begin{array}{l}\text { conservation contest" } \\
\text { to encourage Thai youth } \\
\text { to join the campaign, } \\
\text { using the imagination } \\
\text { to convey the literary } \\
\text { read out as a painting } \\
\text { of their own imagination }\end{array}$ & (Size A2) up & $\begin{array}{l}\text { color techniques } \\
\text { which depends on } \\
\text { the competitor's } \\
\text { skill }\end{array}$ & & \\
\hline $\begin{array}{l}\text { Toyota Dream Car } \\
\text { Art Contest }\end{array}$ & $\begin{array}{l}\text { To give the young } \\
\text { people an opportunity } \\
\text { to express their creativity } \\
\text { and imagination through } \\
\text { the use of art as a medium } \\
\text { in the drawing and painting }\end{array}$ & $\begin{array}{l}\text { Under } 8 \text { years old } \\
\text { Age } 8-11 \text { years old } \\
\text { Age } 12-15 \text { years old }\end{array}$ & $\begin{array}{l}\text { Topics for the contest } \\
\text { are renewed every year }\end{array}$ & $\begin{array}{l}\text { Paper size } \\
\text { A3 }(297 \times \\
420 \mathrm{~mm})\end{array}$ & $\begin{array}{l}\text { Able to use every } \\
\text { type of color } \\
\text { Do not use digital } \\
\text { techniques }\end{array}$ & $\begin{array}{l}\text { Gold medal certificate } 1-3 \\
\text { The winner will get the } \\
\text { international field trip }\end{array}$ & $\begin{array}{l}\text { The person who } \\
\text { get the highest } \\
\text { score } 1-3 \text { of each } \\
\text { age category is the } \\
\text { winner of national } \\
\text { levels }\end{array}$ \\
\hline
\end{tabular}

freely is the essential of arts subject. The activities should set the method of student's expression widely relate to lesson attention and general environment. The assigned topic should be the significant in daily life, children's life, everyday life or children's experiences such as family, school experinces and what children's intertested in.”

For the scale of works, the art institutes are mainly specify size of works which maybe more or less. The drawing will be a vertical or horizon depends on the artist's skill. The material arts and techniques is mostly assigned works e.g., drawing. Besides, there are many materials for creating arts which Damrong Wong-Uparat said "The creative art for kids is mainly limitless materials and techniques because the ability and skill of children are different." The main point is the criteria of rewards is principally similar such as excellence reward, outstanding reward, honor mention reward or creative reward with bills and certificate or souvenirs. The committee sometimes consider giving a trophy for the school which supports art, especially. Kamchorn soonpongsri said "award is an appreciated thing giving by some groups or someone which can be the position, prestige or money for works, behaviors or others."

The result of awards and famous is a successful of art teaching that means the more school gets awards, the more school is successful and if the school do not get any rewards, the school is failure in art teaching. Art education philosophy in school system is changed when the school educate students for their achievements exchange the rewards. There is less opportunity to get the rewards, if the school teach the students follow the courses by emphasizing preparation and support the student which regard as art is a tool for developing to appreciate quality. On the contrary, for more opportunity to get the rewards, the school should select the talented students or who is interested in art for the particular courses like assigned topic studying, background studying, the attitude of the committee, competitor's studying. Therefore, the rewards giving is an argument; inspiration or badness that means we are making a consumer or artist.
The criteria of assessing children's artwork should emphasize the policy responding or the purpose of each art competition, remind the advantages of competition in art education for kids, consider the maturity of each children's age and the development of children, give the opportunity to children fairly to support all of children who love art to express their talent. The imitative works or plagiarism are unconsidered which are the important criteria. The artworks have to be complete as the regulations of competition and the committee have to realize that this is for kids neither adults nor artists (Siburi, 1991). The criteria of evaluating children's artwork should realize general background of children like education, economy and society by considering the creative development of art which express in patterns, contents, the meaning of environment and opportunity, techniques, problem solving.

As the pattern of art competition that mentioned above, it can be seen that the assigned programs of competition such as purposes, competitors, topics, scales of work, materials and techniques, the awards, the criteria of assessing influence to the competitors, especially, children. The art institute and whom it may concern have to survey how much the patterns correspond to children or how much they suitable for kid in order to hold the competition more suitable. The popular activity for supporting kid's art development is drawing contest. There are 2 patterns of the drawing contest which are sending the artwork and attending in the contest. The purposes of the contest are to develop in physical, emotional, social, intellectual include happiness, imagination and confidence. In conclusion, the pattern of art competition of secondary level in Northeastern region are similar, the same attitude or little different as the suitable circumstance or period of time.

Arts teacher's paradigm for arts competition of secondary level in the Northeastern region: For the study of the paradigm of arts teachers for arts competition of secondary level in the Northeastern region, the paradigm of the researcher's terminology refers to concepts, values, perceptions and practice of the arts teachers at secondary level for the arts competition in the Northeast. To study the paradigm in this research, the 
researcher selected 12 arts teachers from secondary school in the Northeast as target groups which can be summarized into 12 teacher's paradigms as in Table 3.

From the table indicating 12 arts teacher's paradigm for arts competition in the Northeast, showing concepts, values, perceptions and practice that are consistent or in one direction as follows:

Concepts of the arts teachers for arts competition of secondary level in the Northeastern region; for the art teaching activities to be for arts competition, the results of the above study summarize the ideas from the 12 teachers who have the same concept or in a similar manner separated as follows:

Promoting teaching and learning activities in the art congregation, art club, based on the above information, there are 3 teachers promoting art teaching activities in art congregation or art club. The concept of Mr. Yongyot Kaeokhao is consistent with Mr. Pramot Kobrat, Mr.
Anuchit Sisuwan and Mr. Kittiphum Phonwisetsit. This shows that art congregation or art clubs can give the children an opportunity to do creative activities in art, allowing children to practice and experience and have self-development.

Organizing teaching and learning activities through the camp process, based on the above information, there are 3 teachers promoting art teaching activities through camp activities, namely Mr. Kitchawat Sansira and Mr. Phiraphong Wongsichan as well as Mr. Kittiphum Phonwisit. This concept indicates that teaching and learning through camp process have more variety than teaching and learning in the classroom can integrate teaching and learning in many ways; organizing activities through various art bases, for instance.

Promotion of competition activities, based on the above information, there are 2 teachers who have ideas for promoting the contest activities, namely, Mr.

Table 3: Shows a comparison of the arts teacher's paradigm to the arts competition in the Northeast

\begin{tabular}{|c|c|c|c|c|c|}
\hline \multirow[b]{2}{*}{ Name-surname } & \multirow{2}{*}{$\begin{array}{l}\text { Knowledge } \\
\text { position }\end{array}$} & \multirow[b]{2}{*}{ Concepts } & \multicolumn{3}{|l|}{ Paradigm } \\
\hline & & & Values & Perceptions & Practice \\
\hline $\begin{array}{l}\text { Mr. Yongyot } \\
\text { Kaeokhao, Ban Huai } \\
\text { Sai Ngua School }\end{array}$ & K 3 & $\begin{array}{l}\text { Promoting teaching } \\
\text { and learning activities } \\
\text { in the art } \\
\text { congregation, art club }\end{array}$ & $\begin{array}{l}\text { Giving children the } \\
\text { opportunity is important }\end{array}$ & $\begin{array}{l}\text { Understanding of the } \\
\text { child's maturity }\end{array}$ & Basics in art \\
\hline $\begin{array}{l}\text { Mr. Pramot Kobrat, } \\
\text { Ban Dong Klang } \\
\text { School }\end{array}$ & K 3 & $\begin{array}{l}\text { Promoting teaching } \\
\text { and learning activities } \\
\text { in the art congregation, } \\
\text { art club }\end{array}$ & Have a passion for art & $\begin{array}{l}\text { Understanding of the } \\
\text { child's maturity }\end{array}$ & $\begin{array}{l}\text { Teaching by } \\
\text { demonstration }\end{array}$ \\
\hline $\begin{array}{l}\text { Mr. Kittiphong } \\
\text { Thammawan, } \\
\text { Sisongkhram } \\
\text { Witthaya School }\end{array}$ & K 2 & $\begin{array}{l}\text { Promoting children } \\
\text { with special talents } \\
\text { in the visual arts }\end{array}$ & $\begin{array}{l}\text { Inspiration from } \\
\text { the teacher }\end{array}$ & $\begin{array}{l}\text { Understanding } \\
\text { of individual } \\
\text { differences }\end{array}$ & Basics in art \\
\hline $\begin{array}{l}\text { Mr. Akkaphong } \\
\text { Sinthao, Nakae } \\
\text { Samakkhi Witthaya } \\
\text { School }\end{array}$ & K 2 & $\begin{array}{l}\text { Promoting competition } \\
\text { activities }\end{array}$ & $\begin{array}{l}\text { Giving children the } \\
\text { the opportunity is } \\
\text { important }\end{array}$ & $\begin{array}{l}\text { Understanding of the } \\
\text { art theory }\end{array}$ & $\begin{array}{l}\text { Students can have } \\
\text { experiment } \\
\text { and research }\end{array}$ \\
\hline $\begin{array}{l}\text { Mr. Kitchawat Sansira, } \\
\text { Chumphae Suksa } \\
\text { School }\end{array}$ & K 3 & $\begin{array}{l}\text { Organizing teaching and } \\
\text { learning activities through } \\
\text { the camp process }\end{array}$ & $\begin{array}{l}\text { Inspiration from } \\
\text { the teacher }\end{array}$ & $\begin{array}{l}\text { Understanding of } \\
\text { individual differences }\end{array}$ & Basics in art \\
\hline $\begin{array}{l}\text { Mr. Anuchit Sisuwan, } \\
\text { Dontan Witthaya } \\
\text { School }\end{array}$ & K 4 & $\begin{array}{l}\text { Promoting teaching and } \\
\text { learning activities in the } \\
\text { art congregation, art club }\end{array}$ & Work experience & $\begin{array}{l}\text { Understanding of the } \\
\text { child's maturity }\end{array}$ & Group process \\
\hline $\begin{array}{l}\text { Mr. Phiraphong } \\
\text { Wongsichan, } \\
\text { Sabmongkhon Witthaya } \\
\text { School }\end{array}$ & K 3 & $\begin{array}{l}\text { Organizing teaching and } \\
\text { learning activities through } \\
\text { the camp process }\end{array}$ & Have a passion for art & Individual differences & $\begin{array}{l}\text { Teaching by } \\
\text { demonstration }\end{array}$ \\
\hline $\begin{array}{l}\text { Mr. Yom Da } \\
\text { Mr.ongchuea, Suksa } \\
\text { Songkhro Thawatburi }\end{array}$ & K 3 & $\begin{array}{l}\text { Promoting competition } \\
\text { activities }\end{array}$ & $\begin{array}{l}\text { Inspiration from the } \\
\text { teacher }\end{array}$ & $\begin{array}{l}\text { Understanding of the } \\
\text { child's maturity }\end{array}$ & $\begin{array}{l}\text { Teaching by } \\
\text { demonstration }\end{array}$ \\
\hline $\begin{array}{l}\text { Mr. Wirayut } \\
\text { Phetpraphrai, } \\
\text { Soengsang School }\end{array}$ & K 4 & $\begin{array}{l}\text { Organizing teaching and } \\
\text { learning activities through } \\
\text { the camp process }\end{array}$ & $\begin{array}{l}\text { Inspiration from the } \\
\text { teacher }\end{array}$ & $\begin{array}{l}\text { Understanding of the } \\
\text { art theory }\end{array}$ & $\begin{array}{l}\text { Teaching by } \\
\text { demonstration }\end{array}$ \\
\hline $\begin{array}{l}\text { Mr. Surichai Siribun, } \\
\text { Than Prasatphet } \\
\text { Witthaya School }\end{array}$ & K 4 & $\begin{array}{l}\text { Promoting children with } \\
\text { special talents in the } \\
\text { visual arts }\end{array}$ & $\begin{array}{l}\text { Giving children the } \\
\text { opportunity is important }\end{array}$ & $\begin{array}{l}\text { Understanding of the } \\
\text { child's maturity }\end{array}$ & $\begin{array}{l}\text { Internet search } \\
\text { for information }\end{array}$ \\
\hline $\begin{array}{l}\text { Mr. Kittiphum } \\
\text { Phonwisetsit, Nangrong } \\
\text { Phitthayakhom School }\end{array}$ & K 3 & $\begin{array}{l}\text { Organizing teaching and } \\
\text { learning activities through } \\
\text { the camp process }\end{array}$ & $\begin{array}{l}\text { Inspiration from the } \\
\text { teacher }\end{array}$ & $\begin{array}{l}\text { Understanding of the } \\
\text { art theory }\end{array}$ & Basics in art \\
\hline $\begin{array}{l}\text { Ms. Chaloemkhwan } \\
\text { Supingkhlad, Mueang } \\
\text { Surin School }\end{array}$ & K 3 & $\begin{array}{l}\text { Applying technology in } \\
\text { art teaching }\end{array}$ & Have a passion for art & $\begin{array}{l}\text { Understanding of } \\
\text { individual differences }\end{array}$ & Group process \\
\hline
\end{tabular}


Atthaphong Sinthao and Mr. Yom Da Mr. ongchuea, encouraging children to participate in drawing competition in various activities of both public and private contest institutes to gain experience and to test the competition arenas for the children. This can give the children a good chance as experience is key to success.

Promoting children with special talents in the visual arts, for the concept of promoting children in visual arts talent, there are two teachers who use this concept-Mr. Kittiphong Thammawan and Mr. Surichai Siribun, to promote children with special talents in the visual arts in both promoting the children who are good at art and children who are not good at art but have a love or passion for art.

Using technology to apply to the teaching of art and making online lessons, from the above information, there are 2 teachers, namely Mr. Kitchawat Sansira and Mr.s Chaloemkwan Supingkhlad. It can be seen that applying integrated technology to the art teaching is important for the creative processes and artwork, resulting in success in the drawing competition of institutes, both the government and institutes from various organizations.

For concepts of the art teachers, according to study, it has been summarized that the informants showed the same concept or in a similar manner. The researcher considers that the concept of the 12 teachers in organizing special teaching activities or learning activities other than the scheduled class is a creative activity to promote teaching and learning activities; for instance in the art congregation or art club or to organize teaching and learning activities through the art camp process, held both internally and externally. From the network of art teachers in the Northeastern region, this results in the promotion of competitions, academic skills competitions from the public and private agencies by applying technology to the art teaching as students can search for information in artwork and designing to create work pieces with new looks, leading to practical work for the competition, resulting in receiving awards from various arts competition. This later results in promoting the children with special talents in the visual arts to further study. The concept of all the 12 teachers correspond or go in the same direction which has a positive effect on teachers, students and related parties.

Values, refers to beliefs or satisfaction or the inspiration of the arts teachers for the arts competition of secondary level in the Northeast. In the matter of organizing arts teaching activities to have the students eligible for an arts competition. Findings witnessed that all the 12 teachers showed the same values or similar in manner, separated as follows:

Giving children the opportunity, based on the above information, 3 teachers showed the same values of giving opportunities to children, namely Mr. Yongyot Kaeokhao, Mr. Atthaphong Sinthao and Mr. Surichai
Siribun, in giving children the opportunity to learn art and promote the students to have a love of art, to see the importance of art.

Have a passion for art, For this value, 3 teachers Mr. Pramot Kobrat, Mr. Phiraphong Wongsichan and Mr.s. Chaloemkwan Supingklad corresponded to the same value. They all agreed with the fact that art can be good for the mind of students. Art can result in the mind concentration can heal physically and mentally. Children who work in art together can live together in harmony which would good benefit for the art competition.

Inspiration from teachers, 4 teachers Mr. Kittiphong Thammawan, Mr. Kitchawat Sansira, Mr. Kittiphum Phonwisetsit and Mr. Yom Da Mr. ongchuea whose values are to create work of art indicated the importance of inspiration from teachers as value for arts teaching. The 4 teachers have a consistent opinion about being inspired by their teachers who are of good example in studying, working and living. They are all good model in teaching art for the benefit of children and able to lead to success in all aspects.

Work experience, 1 teacher Mr. Anuchit Sisuwan, values work experience. Having work experience of an art teacher, applying a teaching process the same way the older teaches the younger, this can affect academic performance positively and bring work experience to be a mentor for friended teachers as well as being an instructor to give various techniques used in performing art.

For values that the 12 teachers share the same or in a similar manner, the study finds that the values mentioned here are that teachers believe that giving children the opportunity is extremely important. If not giving children the opportunity to study, student's potential in studying art will not be seen. Anyway, giving the opportunity to the child with no love for art would not produce any good results for teachers and students either. Art teachers must have a love for their profession have a passion for art, love to teach art, love their job and devote to the role of teachers in organizing teaching and learning activities directly into students. Some of the important inspirations were inspired by their teachers who had taught them long before. They received both the concept of work, the concept of the practice of teaching art to the students and values of the occupation how to master themselves and how to manage the family. To teach the following students, work experience is important for the teachers to apply various theoretical principles to organize teaching and learning activities, preparing for arts competition.

Perceptions of the arts teachers for arts competition of secondary level in the Northeastern region in the matter of organizing art teaching activities for the arts competition, the study found that the ideas from the 12 teachers who shared the same understanding or were similar in manner are classified as follows: 
Child's maturity, based on the above information, there are 5 teachers who have a good understanding of the child's maturity, namely Mr. Yongyot Kaeokhao, Mr. Pramot Kobrat, Mr. Anuchit Sisuwan, Mr. Yom Da Mr. ongchuea and Mr. Surichai Siribun. It can be seen that all the 5 teachers have a good understanding of the child's maturity, potential of work, basic skills in art, understanding that students may possess an unequal perception in art. The readiness of the children affects the arts competition. The importance is that teachers need to be aware of this matter and understand the child's basics of artwork. If the child receives correct training, it will be forwarded to the artwork and to the arts competition as well.

Differences between individuals, based on the above information, there are 4 teachers who understand the differences between people, namely, Mr. Kittiphong Thammawan, Mr. Kitchawat Sansira, Mr.s Chaloemkwan Supingklad and Mr. Phiraphong Wongsichan. It can be seen that the 4 teachers shared the same understanding about the differences of children. What they shared in common is they understand each of the children individually, understand the basic family of the children, different psychological fundamentals; these can enable a teacher to understand the child's identity. Understanding about the children is important in arts teaching activity organization, resulting in the encouragement of the children to perform well in art.

Art theory, based on the above information, there are 3 teachers who understand the matter of art theory-Mr. Atthaphong Sinthao, Mr. Kitthiphum Phonwisetsit. There is a perception that is consistent with Mr. Wirayut Phetpraphai in that the knowledge of academic principles can be used in organizing learning activities and using in artwork-color theory, elements of art, visual elements, basic skill in arts.

Perceptions of all the 12 teachers who have the same perception or in a corresponding way. The study can be concluded that the teachers must have an understanding of the maturity of each child that are different in each age, differences between individuals. The teachers must know a child on an individual basis, able to understand the child's work potential. Art theory, knowledge about academic principles can be used in organizing activities, learning and using in artwork, namely color theory, elements of art, visual elements, basic skills in art, resulting in the child's readiness for an arts competition. It is important the teachers must have a basic understanding of artwork. If the child receives the correct knowledge, it will be forwarded to the work of art and to the arts competition effectively.

Practice for an arts teacher of secondary level for arts competition in the Northeast, regarding organizing art teaching activities, preparing for an arts competition, the results of the above data analysis showed that the ideas from the 12 teachers who have the same concept or are similar in manner can be classified as follows:

Teaching by demonstration, based on the above information, there are 4 teachers who practice in teaching by demonstration- Mr. Pramot Kobrat, Mr. Phiraphong Wongsrichan, Mr. Yom Da Mr. Ongchuea and in accordance with the practice of Mr. Wirayut Phetpraphai. It can be seen that the teachers have a demonstration for children to see step by step clearly, according to the learning process. For the work of students, teachers gave advice on artwork, focusing on skills and work processes that are systematic steps, resulting in practices that promote the student's work of art

Basic art, Based on the above information, there are 4 teachers who have practiced in the art basics-Mr. Yongyot Kaeokhao, Mr. Kittiphong Thammawan, Mr. Kittiphum Pholwisetsit and in correspondence with the practice of Mr. Kitchawat Sansira. It can be clearly seen the 4 teachers practice by providing knowledge and basic techniques in visual elements, elements of art and color theory including the principle of modern design, applying the main theory to organizing teaching and learning activities and working on art to performing it perfectly at last

Group work process, Based on the above information, Mr. Anuchit Sisuwan has performed practices in the group process. Many techniques and styles were applied for the teaching, especially, the father-and-son teaching style, one-on-one or friends-to-friends teaching style. The teacher can guide in accordance with the teaching system. This corresponds with Mr.s Chaloemkwan Supingklad. The practice is using teaching techniques that will focus on learning together and working together to achieve mutual recognition, able to work in art with pleasure.

For practice of the 12 teachers who have the same practice or in a similar manner. The study indicated that practice is taught by demonstration. Art teachers have to be able to showcase artwork as it is a skill-oriented subject, needs to develop a piece of artwork. To create a particular work of art, the art teachers must have a demonstration on how to develop the work step by step, must showcase the clear work process. If the children see the demonstration from the teacher, they will be able to understand more in the working process. Ability to create artwork of most students is a result from group working process while the teacher lets the student to take action by working in the group process. At the same time, introduction to working one-on-one, friends-to-friends, teacher's guidance on techniques how to learn and work together, students will achieve mutual recognition and be able to work in art with pleasure. What they have learned directly affects themselves, to conclude. 
According to the study, it can be summarized that the paradigm of 12 arts teachers, from 12 schools in the Northeast, consists of concepts, values, perceptions and practice. For the arts teacher's paradigm for the secondary level arts competition in the Northeast, it can be said that the paradigm of the 12 teachers is useful and important to the study of arts teacher's paradigm which means concepts, values, perceptions and practice of arts teachers for the secondary school arts competition in the Northeast. For the 12 teacher's paradigm, it has the same paradigm in 4 aspects that share similar directions. For some issues of all the 4 paradigms from 12 teachers, some of which that share similar and not similar characteristics indicated that the paradigm of the 12 teachers from the concepts, values, perceptions, to practice. For the organization of arts teaching activities for the secondary level arts competition in the Northeast, there are both good and bad results for teachers, students and related people. The paradigm is the change of concepts that occur over a period of time; it can change anytime, uncertain but stable. The paradigm can arise in a period of time that has been changed has been adjusted with an application and with new reforms to suit any context with one group of people with an appropriate occasion. Each teacher's paradigm can have concepts, values, perceptions that can be similar or different to lead to appropriate practices for the environment of secondary schools in the Northeast.

Secondary level: The core curriculum for the basic education (2008's Revised Edition), focuses on the important competencies of learners, i.e., communication ability, thinking ability, ability to solve problems, ability to use life skills, ability to use technology. This aims to develop learners to have the desirable characteristics in order to be able to live happily with others in the society as a Thai and the world citizen. The level of education related to the research is as follows:

Lower secondary level (Mattayom 1-3) is the level of education that focuses on students to explore their own aptitudes and interests, promote personal personality development, have critical thinking skills, creativity and problem-solving skills, having the skills to use technology to be a learning tool having social responsibility, having balance in terms of knowledge, ideas, goodness and being proud of Thainess as well as a basis for occupation or further education

Upper secondary level (Mattayom 4-6) is the level of education that focuses on increasing knowledge and specific skills to respond to the abilities, aptitudes and interests of each student in both academic and professional aspects having the skills to apply science and technology have advanced thinking process skills and can apply knowledge to be useful in further education and career development, aiming to develop one's self and the country according to his or her role can be a leader and community service provider in various areas. However, the standards of schools in Thailand are still inequality. Therefore, students prefer to go to extra study in various forms. The curriculum organizes teaching and learning activities in the form of special supplementary teaching and integration to encourage students to have more learning skills in order to be suitable for the specific needs preferably for the students. The courses offered in each school will have different characteristics for the suitability of each school (Jongsumamal, 2003)

It can be seen that the teaching and learning of art education at the secondary level is important to the arts teachers that must have an understanding of the behavior of the students. Art teachers must study and find ways to arrange art instruction for art competitions that can meet all the needs of secondary school students. Students have their own creativity and the potential to submit their work to any of the arts competition institutes mentioned above.

The Northeast of Thailand: The study on arts competition at the secondary level in the northeast or Esan refers to 20 provinces including Kalasin, Khon Kaen, Chaiyaphum, Nakhon Phanom, Nakhon Ratchasima, Buriram, Maha Sarakham, Mukdahan, Yasothon, Roi Et, Si Sa Ket, Sakon Nakhon, Surin, Nong Khai, Nong Bua Lamphu, Amnat Charoen, Udon Thani, Ubon Ratchathani and Bueng Kan with an area of approximately $170,226 \mathrm{~km}^{2}$ or one-third of the whole country. For geographical features, the region is located on Korat plateau terrain; the whole region is elevated at the edges and is clearly separated from the central region of Thailand. The Northeast is a land where people have lived since the past. Each of the communities has developed continuously until it becomes a state. With many ancient community sites scattered around the Chi river basin and Mun river basin which is divided into Dvaravati culture group, known for making oval-shaped or circle-shaped ditches around the city. They normally set up a city near the water source to facilitate the draw of water into the moat. Khmer culture groups preferably have their city plan in a square shape with Barays (reservoirs) excavated as a water source in the city. The word "Esan" was first used in 1913 in the reign of King Rama VI or when there was a royal command to include Udon Thani county, Ubon Ratchathani county and Roi Et county into the Northeast. The regional government was headquartered in Udon Thani for Chao Phraya Mukhamontri to be the viceroy of the Northeast and to be Intendant of Udon Thani County as well. In March, 1925, during the reign of King Rama VII, Thailand has suffered the economic downturn, resulting in many cancellations of the announcement of the Northeast region as well as the collapse of Ubon Ratchathani and Roi Et counties to become a province status governed by Nakhon 
Ratchasima county until the end of the absolute monarchy in 1932 (Wipak-Pojanakij, 1999). The institute of arts competition in the Northeast plays an important role for the art education of secondary schools. About 4 schools in the upper-Northeast, 5 schools in the middle-Northeast 2 schools as well as 5 schools in the lower-Northeast, totalling 12 schools have been rewarded from arts competitions. The awarded artworks were unique with the expression of Esan local culture and tradition, indicating the way of life of the local people and portrayed the story through artworks in visual arts perfectly.

The researcher summarizes a new body of knowledge from the study findings, site-survey, collecting data from relevant research studies. The summary of the knowledge gained is that PARADIGM is the paradigm where CONVAPP comes from the abbreviations of concepts, values, perceptions and practice. It can be summarized in the Fig. 9. The new body of knowledge is CHANGE, a change of concepts that can occur in a certain period of time and can change at any time. The 12 arts teachers has concepts that are both similar and different. The concept of organizing art teaching activities for the arts competition has a period of time that can change according to each situation as appropriate. Adaptation, all 12 art teachers can adapt the arts teaching to suit the arts competition. Each person has to adapt to the situation. In the era of technological progress, ones should adapt themselves every moment to perform the artwork and organize art teaching classes to suit the social change for appropriateness, opportunity and world's modernity. Currently, application, all the 12 arts teachers have applied to new applications in art teaching for arts competition. Each of the teachers use new applications in the field of artwork, both in terms of teaching methods, innovation of teaching media, techniques for creating works of art that are unique in every time in order to keep up with the events or situations that are constantly changing. Reformation, there have been new reforms for all the 12 arts teachers in teaching art for arts competition preparation. There are new reforms used in the artwork to suit any context with one group with appropriate opportunities. The paradigm of the 12 teachers can vary

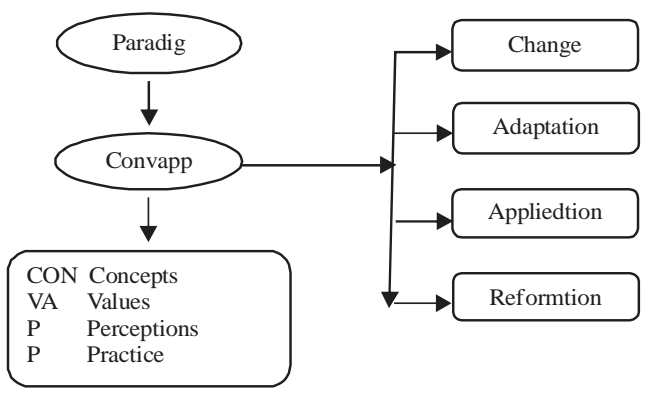

Fig. 9: Diagram of new body of knowledge summary with concepts, values, perceptions that can be similar or different to lead to an appropriate practice that suits the environment of secondary school level in the Northeast. The results can be both good and bad for teachers, students and related people. Therefore, the arts teacher paradigm for the secondary school arts competition in the Northeastern region causes a change, adjustment, application and revolution in the concepts, values, perception and practice that can occur during a certain period of time and can change every time. Results of this study show the importance of the arts teaching paradigm to create works of art in each era.

\section{CONCLUSION}

Results of the study on “The Arts Teacher's Paradigm for Arts Competition of Secondary Level in Northeastern Region” can be summarized as follows. According to objective 1: to study the history of arts competition of secondary level in the Northeast, it can be concluded that for the history of the institutes of arts competition in the Northeast, there have been institutes for arts competition affiliated to the government sector, namely Esan Excellence Fair, institute of arts competition affiliated to the Office of the Higher Education Commission such as PTT art competition for Northeastern youths. In addition, it also includes companies that have visual art drawing contest held for students from elementary school level to high school level, from tertiary level to general youth. The institutes of secondary level arts competition in the Northeast is important to teachers as it can be seen that they occasionally send students from junior high school and upper secondary school to participate in the drawing contest continuously. The secondary school arts teachers in the Northeastern region have the needs and are interest in sending students to participate in the drawing contest competition at all the 8 institutes as they could be proud of the prizes and reward at the school which showcases the great reward that the student teacher receives clearly appeared as the award of reputation, promotion of academic work position and the social acceptance that all play an important role. According to objective 2: to study the paradigms of art teachers of secondary level arts competition in the Northeast, for paradigm of arts teachers for arts competition of secondary level in the Northeast. In brief, "paradigm", according to the definition of the researcher's term, means concepts, values, perceptions, practice of arts teachers for secondary level arts competition in the Northeast. The 12 teachers share the same paradigm in all 4 aspects or with similar directions, as well as all the 4 paradigms from the 12 teachers that some of which are different or altered characteristics, can indicate that the paradigm of the 12 teachers includes concepts, values, perceptions and practice that are all 
applied to organizing arts teachinc activities for the arts competition of secondary level in the Northeast. There are both good and bad results for teachers, students and related people. The paradigm is the change of concepts that occur over a period of time; it can change anytime, uncertain but stable. The paradigm can arise in a period of time that has been changed has been adjusted with an application and with new reforms to suit any context with one group of people with an appropriate occasion. Each teacher's paradigm can have concepts, values, perceptions that can be similar or different to lead to appropriate practices for the environment of secondary schools in the Northeast. The paradigm of the 12 teachers from the concepts, values, perceptions and practice can be applied to organizing arts teaching activities for the preparation for secondary level arts competition in the Northeast.

\section{SUGGESTIONS}

The study result can be implied to the significant of paradigm in arts teaching for creativity in each era and can be an example of knowledge used to understand the paradigm of other arts teachers, either in the Northeast or the arts teacher all over the country which is useful for the direction of the development of creative arts in the future.

\section{REFERENCES}

Anonymous, 2003. Learning management for art learning area. Ministry of Education, The Teachers Council of Thailand, Bangkok, Thailand.
Anonymous, 2007. KhonKaen Northeastern news center. Manager Daily, Thai.

Anonymous, 2016. Thai literature conservation contest with in touch project. Imagination Publishing L.L.C., Chicago, Illinois, USA.

Jongsumamal, P., 2003. Parents and students attitudes towards academic administration in the non-formal private schools : A case study of Sriprasert Tutoring School, Amphur Muang, KhonKaen Province. Master Thesis, Khon Kaen University, Khon Kaen, Thailand.

Siburi, S., 1991. Viewpoints of Curriculum Development Experts, Visual Art Academics and Art Curriculum Users in the Lower Secondary School Curriculum. Graduate School, Chulalongkorn University, Bangkok, Thailand,.

Supanimit, P., 2010. The 25-Year Journey with PTT Art Competition. Amarin Printing and Publishing, Bangkok, Thailand,.

Toshiba, 2017. Toshiba news...brings good things to life. Toshiba Thailand Company, Bangkok, Thailand.

Wattanasin, W., 2003. Secondary School Art. Prince of Songkla University Pattani Campus, Rusamilae, Thailand,.

Wipak-Pojanakij, T., 1999. Isan History. 3rd Edn., Thammasat University, Bangkok, Thailand,.

Yuvabadhana Foundation, 2016. Yuwaphat Foundation provided scholarships for the future of Thai children. Yuvabadhana Foundation, Thailand. 